\title{
Virus-like particle analysis in a seston-rich coastal pond using transmission electron microscopy
}

\author{
H. Montanié ${ }^{1, *}$, H. J. Hartmann ${ }^{1}$, C. Crottereau ${ }^{2}$, C. Trichet ${ }^{1}$ \\ ${ }^{1}$ Laboratoire de Biologie et Environnement Marins, EA 3168, Université de La Rochelle, Avenue Michel Crépeau, \\ 17042 La Rochelle, France \\ ${ }^{2}$ CNRS/IFREMER, Unité mixte de recherche 10, Centre de Recherche en Ecologie Marine et Aquaculture L'Houmeau, BP 5, \\ 17137 La Rochelle, France
}

\begin{abstract}
A method was developed to analyse virus-like particles (VLPs) in seston-rich waters and to quantify their dynamics in a coastal marsh of the Bay of Biscay, French Atlantic coast. The method combined clarification and concentration steps with electron microscopy to obtain information on particle abundance, type and size distribution (e.g. presence of tailed phages, Fuselloviridae, etc.). The mean recovery rates of T2-phages using this method were 71 to $79 \%$, higher than other published rates. The transmission electron microscopy (TEM) counts were validated with T2 plaque lysis assay and epifluorescent (DAPI-stained) particle counting: the TEM method was valid for environmental particle concentrations above 1 to $2 \times 10^{6} \mathrm{VLP} \mathrm{ml}^{-1}$; TEM counts were lower than T2plaque counts $($ TEM/lysis median $=0.293)$ but higher than DAPI counts (TEM/DAPI median $=2.39$ ). The method was used to evaluate the coupling between viral and bacterial dynamics in a marsh pond during 2 months. The VLP abundance varied from 1 to $30 \times 10^{6} \mathrm{ml}^{-1}$ and the viral population was dominated by small particles (20 to $64 \mathrm{~nm}$ ). Tailed phages, identified as bacteriophages, were always less abundant than non-tailed VLPs (4 to $23 \%$ of total virus), yet their dynamics were better linked with bacterial development than those of total virus. Our results demonstrate that the best way to characterise bacterial lysis from virus in seston-rich coastal environments would be to study the dynamics of tailed phages and virus size-classes rather than the commonly applied total VLPs.
\end{abstract}

KEY WORDS: Virus enumeration $\cdot$ Seston-rich water $\cdot$ TEM $\cdot$ DAPI $\cdot$ Virus-bacteria dynamics

\section{INTRODUCTION}

The recycling of dissolved organic primary production back into biomass by aquatic bacteria, as a part of biological transformations occurring within the microbial loop, was described during the 1970s and 1980s (e.g. Pomeroy 1974, Azam et al. 1983). The role of viruses in the structure and function of aquatic microbial webs was taken into account only after high viral abundance in sea waters had been reported $\left(10^{6}\right.$ to $10^{8} \mathrm{ml}^{-1}$; Bergh et al. 1989, Bratbak et al. 1990, Proctor \& Fuhrman 1990, Suttle et al. 1990). Recently, in using a revised model of Jumars et al. (1989), Wilhelm \& Suttle (1999) estimated that 6 to $26 \%$ of photosyntheti-

*E-mail: helene.montanie@univ-lr.fr cally fixed particulate organic carbon was recycled back to dissolved organic matter (DOM) by viral lysis (which liberates dissolved and particulate organic matter as well as virions). Thus, as much as one-fourth of the organic carbon in the sea flows through the viral shunt. In contrast, heterotrophic flagellates and other bacterivores only recycle $9 \%$ (Wilhelm \& Suttle 1999).

During the last decade, viral ecologists have studied a variety of aquatic habitats, mainly rivers and lakes (Maranger \& Bird 1995, Mathias et al. 1995), estuarine waters (Cochlan et al. 1993), coastal waters (Boehme et al. 1993), deep-sea waters (Hara et al. 1996), deep-sea sediments (Danovaro \& Serrest 2000), sea ice (Maranger et al. 1994) and solar salterns (Guixa-Boixareu et al. 1996). In reviewing these and other works, Wommack \& Colwell (2000) found that virus concentrations are relatively high in productive and nutrient-rich 
environments, and greater in spring through autumn than in winter.

Viruses have not yet been studied in coastal marine marshes, which are important ecosystems for both sustainable use (e.g. mariculture) and conservation. In the Atlantic region of SW France, oysters are cultured in semi-enclosed coastal marsh ponds ('claires'). These ponds exhibit high concentrations of suspended particulate matter, nutrients and DOM (Robert et al. 1982). Together, they support bacterial abundances 10-fold higher than in the open sea (Frikha et al. 1987, Crottereau \& Delmas 1998), as well as high concentra-

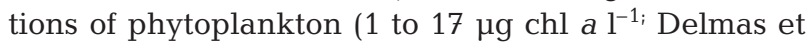
al. 1992) and protozoa $\left(0.1\right.$ to $20 \times 10^{6}$ flagellates and 0.5 to $8 \times 10^{4}$ ciliates $1^{-1}$; Dupuy et al. 2000). In order to assess virus abundance in these seston-rich waters, we needed to develop a method to separate seston (particles $\geq 0.2 \mu \mathrm{m}$ ) from virus particles.

The purpose of the present paper is to report on the validation of a separation method where a clarification step precedes the concentration of virus for counting. The viruses were quantified by comparing transmission electron microscopy (TEM; Bergh et al. 1989, Hara et al. 1991) and epifluorescence microscopy (Proctor \& Fuhrman 1992). Cultured T2-bacteriophages and plaque assay served as references. The protocol was then applied to field samples from an experimental marsh pond to monitor the change of virus abundance and size-class proportions in relation to bacteria.

\section{MATERIALS AND METHODS}

Virus strains. T2-bacteriophage (ATCC 11303-B2, $5 \times 10^{10} \mathrm{PFU} \mathrm{ml}^{-1}$ ) was purchased from Institut Pasteur (Paris). A viral suspension titer of $1 \times 10^{10} \mathrm{PFU} \mathrm{ml}^{-1}$ was obtained by propagating the phage in Escherichia coli B (strain ATCC 23848) and then concentrating it through ultracentrifugation.

Field sampling. Water was collected from an experimental oyster pond of the CNRS-IFREMER research station on the French Atlantic Coast (L'Houmeau, Bay of Biscay). The pond is one of a series of $200 \mathrm{~m}^{2}$ experimental basins, $1 \mathrm{~m}$ deep, located in the coastal marsh Marais du Plomb near the city of La Rochelle (46 $10^{\prime} \mathrm{N}$, $\left.1^{\circ} 15^{\prime} \mathrm{W}\right)$. The coastal ponds were dug in clay sediments 15 yr ago. Their flat bottoms are composed of thin layers of silt resulting from sedimentation of marine particles brought by turbid coastal waters and the destabilisation of surrounding terrestrial banks. During spring and summer, half of the water of each basin was drained off at each spring ebb tide and the basins were refilled during the following high tide with coastal water, the flow of which is regulated through locks. The first sampling was made $1 \mathrm{~d}$ after the arrival of the seawater in the pond. The ponds represent semiclosed ecosystems with a lunar renewal cycle (28 to 30 d). Our experimental pond did not contain any oysters or other bivalves during the experimental period.

In June and July 1996, at the beginning, middle and end of each lunar cycle, a volume of 21 was sampled in the morning at half-depth $(0.5 \mathrm{~m})$ using a Van Doorn bottle, pooled from 4 locations of the pond. From the pooled sample, a $100 \mathrm{ml}$ sub-sample was preserved with $2 \%$ (final concentration) glutaraldehyde (Sigma grade I) and stored at $4^{\circ} \mathrm{C}$ until analysis. Samples for enumeration of bacteria were fixed with a borate-buffered formaldehyde $2 \%$ (final concentration).

Concentration and purification of virus-like particles (VLPs). To eliminate bacteria and other microorganisms, $100 \mathrm{ml}$ samples were distributed into $37 \mathrm{ml}$ tubes and clarified by centrifuging for $15 \mathrm{~min}$ at $4000 \mathrm{rpm}\left(3000 \times g\right.$ at the maximum radius, $\mathrm{r}_{\max }$ LE 70 Beckman ultracentrifuge, SW 28.1 rotor). VLPs were then concentrated by pelleting the supernatant of each tube for $3.5 \mathrm{~h}$ at $28000 \mathrm{rpm}\left(150000 \times g\right.$ at $\mathrm{r}_{\text {maxi }} \mathrm{SW} 28.1$ rotor) and resuspending the pellets in $100 \mu \mathrm{l}$ of $\mathrm{TN}$ buffer (0.02 M Tris- $\mathrm{HCl}, 0.4 \mathrm{M} \mathrm{NaCl}, \mathrm{pH}$ 7.4). The efficiency of this method was tested with T2-bacteriophages using $37 \mathrm{ml}$ of untreated pond water. Since the T2-phage is not marine, double-distilled autoclaved water and LB Medium ( $\mathrm{NaCl} 10 \mathrm{~g} \mathrm{l}^{-1}$, bactotryptone $10 \mathrm{~g} \mathrm{l}^{-1}$, yeast extract $5 \mathrm{~g} \mathrm{l}^{-1}$ in Milli-Q water) served as reference media.

Quantification and size distribution of viral suspension. The VLPs of the environmental samples were quantified through TEM and epifluorescence microscopy (DAPI method).

For the TEM method, a drop of $20 \mu \mathrm{l}$ of viral suspension was spread on a parafilm surface. A carbon-collodion coated grid (collodion coating face down) was placed on the drop. Virus thus migrate by capillarity to the grid surface. Without any rinsing, the grid was then negatively stained by transfer for 3 min onto a drop of phosphotungstate (PTA; pH 7). Excess PTA was then drained off with a pointed piece of Whatman paper. Observations were made with a Jeol 100 CX transmission electron microscope operating at $100 \mathrm{kV}$, calibrated with a graphite grid. Either 2 or 3 grids were prepared for each sample. At least 6 to 10 photographs were taken at a magnification of $50000 \times$, in order to count at least 100 particles sample ${ }^{-1}$. The mean coefficient of variation (CV) for replicate grid counts was $29.4 \%$. To evaluate the viral abundance, a conversion factor $(F)$ was applied to the average count for each photograph. For a magnification of $50000 \times$ and a $3.05 \mathrm{~mm}$ grid, $F$ was $3.26 \times 10^{6}$ photographs grid ${ }^{-1}$. 
The ultrastructure of the VLPs was also noted and particles were classified according to form and size. We identified 2 major groups: tailed particles, which all are bacteriophages (Order Caudovirales, Ackermann 2001), and untailed particles. The latter contain lemonshaped bacteriophages (Family: Fuselloviridae; Murphy et al. 1995), some other untailed bacteriophages, and viruses of eukaryotes. In this study, the term 'bacteriophages' is restricted to tailed and lemonshaped phages. The untailed bacteriophages could not be distinguished from the other untailed viruses and were therefore excluded from the bacteriophage category. The term 'total virus' includes all VLPs observed.

For the epifluorescence method, samples were filtered onto a $0.02 \mu \mathrm{m}$ pore size Anodisc membrane (Whatman) stained with Irgalan black solution (Geigy). The stain was obtained by incubating the membranes for $24 \mathrm{~h}$ in a $2 \% \mathrm{w} / \mathrm{v}$ Irgalan black (powder dissolved in boiling water, then adjusted to make a $2 \% \mathrm{v} / \mathrm{v}$ acetic acid solution). The stained filters were mounted on a filtering tower with a pre-moistened nitrocellulose backing filter (pore size $0.45 \mu \mathrm{m}$ ). The viral particles were then stained with a DAPI-solution (4',6diamidino-2-phenylindole) according to Suttle (1993). Viral abundance was estimated by counting the particles under an epifluorescence microscope (Leica DMIRB) at a final magnification of 1000x.

To obtain an estimation of viral abundance from the TEM and DAPI methods, viral abundances were calibrated with the plaque lysis method (Adams 1959). The plaque lysis method is considered to give an accurate evaluation of active viruses. Serial dilutions of T2bacteriophage were quantified by the TEM and DAPI method, and simultaneously titered by the plaque lysis method. Calibration curves were obtained from linear regressions of $\log (\mathrm{TEM})$ vs $\log$ (Plaque Forming Units) and $\log (\mathrm{DAPI})$ vs $\log (\mathrm{PFU})$ counts.

Statistical comparisons were analysed according to Zar (1996) using log-transformed values. The log transformation did not change the results of any of the tests.

Bacterial abundance. Bacteria were counted by epifluorescence microscopy with DAPI (final concentration $2.5 \mathrm{mg} \mathrm{l}^{-1}$ ) according to Porter \& Feig (1980). Different bacterial morphotypes were noted.

\section{RESULTS}

\section{Comparison of TEM, DAPI and plaque lysis methods to estimate viral abundance}

For T2 calibration dilutions between $10^{7}$ and $10^{10}$ PFU $\mathrm{ml}^{-1}$, the overall relation between DAPI and lysis counts was: $\log (\mathrm{DAPI})=-0.556+0.970 \log (\operatorname{lysis})$, where lysis is the number of PFU ml $\mathrm{m}^{-1}$ as determined by plaque assay and DAPI the number of particles $>0.02 \mathrm{~nm} \mathrm{ml} \mathrm{m}^{-1}$ observed by epifluorescence microscopy. This regression is highly significant $\left(\mathrm{r}^{2}=0.989\right.$, $\mathrm{p}<<0.001$, df $=17$ ) and the slope is unity ( $t$-test for the null hypothesis, $\mathrm{H}_{0}$ : slope $=1 ; \mathrm{p}=0.241$, $\mathrm{df}=17$; Fig. 1A). The observed ratio between untransformed DAPI and lysis counts varied from 9 to $22 \%$ (median = 0.152 , mean $=0.158, \mathrm{CV}=27 \%$ ).

TEM analysis was feasible only when T2-titers in the fraction deposited on the grid exceeded $2.5 \times 10^{8}$ PFU ml $\mathrm{m}^{-1}$. When the viral concentration in that fraction was lower, it was impossible to visualise enough particles on a square of the electron microscope screen, and the particle distribution was contagious. The overall relation between TEM and lysis counts was: $\log (\mathrm{TEM})$ $=4.800+0.448 \log$ (lysis) $\left(\mathrm{r}^{2}=0.775, \mathrm{p}<<0.001, \mathrm{df}=\right.$ 13). The observed TEM/lysis ratio varied from 0.07 to 9.33 (median $=0.293$, mean $=1.72, \mathrm{CV}=158 \%)$. The median here best represents the general tendency of the results, since most of the ratios $(73.3 \%)$ were $<1$, while those $>1$ generally corresponded to the lowest observed concentrations $\left(\leq 1 \times 10^{8} \mathrm{PFU} \mathrm{ml}^{-1}\right.$; Fig. 1B).

When comparing TEM and DAPI counts, the relationship appeared similar to that obtained with TEM-lysis data: $\log ($ TEM $)=4.947+0.474 \log (\mathrm{DAPI})$ $\left(\mathrm{r}^{2}=0.790, \mathrm{p}<<0.001, \mathrm{df}=13\right.$; Fig. 1C). In fact, the slopes of these 2 regressions were not significantly different ( $t$-test for comparison of slopes: $\mathrm{H}_{0}: \beta_{1}=\beta_{2 i} \mathrm{p}=$ 0.847 ; df $=28$ ), while the intercepts differed from each other ( $t$-test for comparison of elevations : $H_{0}: \alpha_{1}=\alpha_{2}$ i $\mathrm{p}=0.0011$; df = 27)

Six environmental samples from the pond were also quantified by TEM and DAPI methods. The data were plotted together with the T2-phage data (Fig. 1D). The TEM-DAPI regression of these combined data $\left(\log (\right.$ TEM $)=4.938+0.476 \log (\mathrm{DAPI}) ; \mathrm{r}^{2}=0.800, \mathrm{p}<<$ 0.001 , df $=27$; Fig. 1D) was not significantly different from the regression of the T2-phage data alone ( $t$-test for comparison of slopes: $\mathrm{H}_{0}: \beta_{1}=\beta_{2 i} \mathrm{p}=0.987, \mathrm{df}=34$; $t$-test for comparison of elevations: $\mathrm{H}_{0}: \alpha_{1}=\alpha_{2} ; \mathrm{p}=$ 0.904 , df $=33$ ). For these combined data, the observed ratio of TEM/DAPI varied between 0.40 and 41.2. Most values $(71.4 \%)$ ranged between 1 and 10 (median = 2.39 , mean $=7.39, \mathrm{CV}=163 \%$ ). As for the DAPI/lysis calibrations, the high ratios (TEM/DAPI > 3) generally were associated with the lowest concentrations $(\leq 1 \times$ $10^{8}$ DAPI-virus $\mathrm{ml}^{-1}$; Fig. 1B).

\section{Concentration method}

To evaluate the virus recovery efficiency of the rotor and the resuspension of the particles, a known concentration of T2-phage was pelleted using the same 

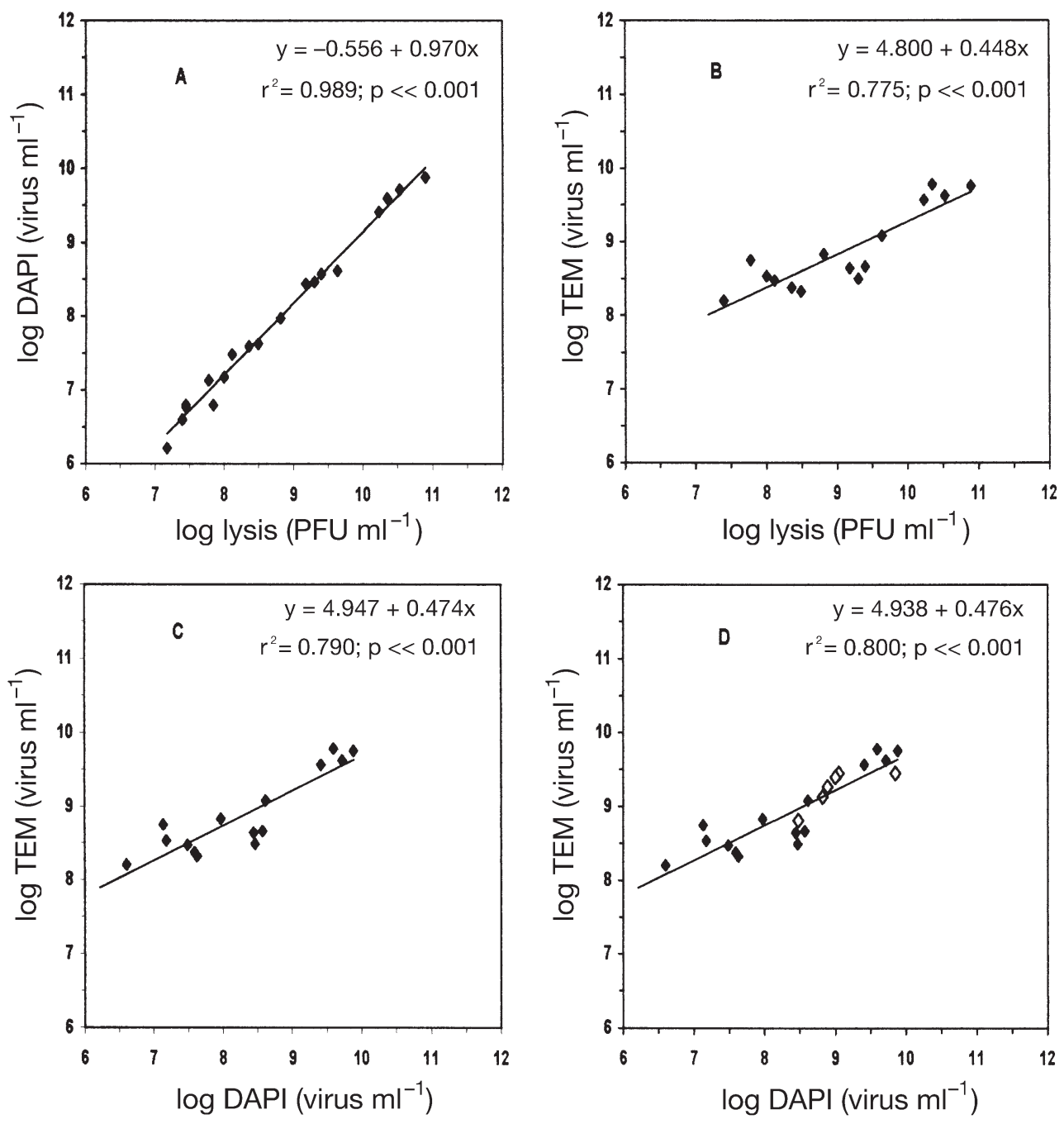

Fig. 1. Calibration curves of DAPI and TEM counts of T2-phages compared to T2 plaque assays ( in A and B), and of T2 TEM counts compared to T2 DAPI counts (C). In (D), total TEM-DAPI count data of natural virus sampled from the experimental oyster pond $(\diamond)$ are added to the data of $(C)$. For statistical comparisons of the regression lines (B) with (C) as well as (C) with (D), see text

method as for the field samples. Two methods were used for quantification: TEM and plaque assay (Table 1). Preliminary assays with T2-phage showed that there was no significant loss of phages due to clarification. Plaque assays yielded recovery rates of $70.8 \pm$ $12.9 \%$ and $74.1 \pm 24.5 \%$, respectively, for T2-phages inoculated in LB medium or distilled water without clarification, and $78.8 \pm 9.9 \%$ in LB medium with clarification. Clarification loss was minimal $(0.21 \pm 0.05 \%$ in LB medium). TEM assays yielded similar recovery rates $(77.3 \pm 2.5 \%$ with clarification), yet somewhat higher clarification loss rates $(2.55 \pm 0.56 \%)$. Moreover, the TEM assay allowed the distinction of full phages (most likely healthy virions) and defective phages. The latter were empty, disrupted or tailless phages.
In seawater, the recovery rate of T2-phages was very low (e.g. $22.9 \pm 5.4 \%$ for plaque-assayed phages and $35.0 \pm 11.3 \%$ for TEM-assayed phages). Nevertheless, the clarification loss was comparable to that of phages inoculated in LB medium $(0.17 \pm$ $0.04 \%$ and $2.34 \pm 0.21 \%$, respectively). In the TEM assays, we found a large percentage of defective particles (nearly $2 / 3$ of all recovered particles). The microphotographs of the latter revealed a rather great proportion of engorged and partially disrupted particles, as compared to the T2-particles in LB medium.

Very few detached tails were seen (nearly none in LB medium and some in seawater). They were not quantified, but were less abundant than tailless particles. 
Table 1. Evaluation of the virus concentration method. A T2 phage suspension was inoculated into 3 media (bacterial medium [LB], distilled $\mathrm{H}_{2} \mathrm{O}$, untreated pond water [SW]). Particles were ultracentrifuged with or without a preliminary clarification step. Shown are the overall recovery rate (the means $\pm \mathrm{SE}$ of the ratio of T2 particles in the final pellet, after untracentrifugation, over the initial T2 count) and of the clarification loss rate (ratio of the T2 particles in the clarification pellet over the initial T2 count). The average initial T2 counts in LB and SW were 99.1 and $85.4 \%$, respectively, of their inoculum titers. The T2 particles were counted by plaque assay (top) and by TEM assay (bottom); $\mathrm{n}=3$, except where stated otherwise

\begin{tabular}{|lccc|}
\hline & LB & $\mathrm{H}_{2} \mathrm{O}$ & $\mathrm{SW}$ \\
\hline T2 plaque assay & & & \\
Recovery rate (\%) & & & \\
With clarification & $78.8 \pm 9.9$ & - & $22.9 \pm 5.4$ \\
Without clarification & $70.8 \pm 12.9$ & $74.1 \pm 24.5(\mathrm{n}=2)$ & $26.5(\mathrm{n}=1)$ \\
Clarification loss (\%) & $0.21 \pm 0.05$ & - & $0.17 \pm 0.04$ \\
T2 TEM assay & & & \\
Recovery rate (\%) & $77.3 \pm 2.5$ & - & $35.0 \pm 11.3$ \\
Full, tailed particles & $65.6 \pm 2.4$ & - & $13.8 \pm 6.4$ \\
Defective particles & $11.7 \pm 4.1$ & - & $21.2 \pm 5.2$ \\
Clarification loss (\%) & $2.55 \pm 0.56$ & - & $2.34 \pm 0.21$ \\
Full, tailed particles & $1.16 \pm 0.54$ & - & $\mathrm{ND}$ \\
Defective particles & $1.38 \pm 0.37$ & - & $\mathrm{ND}$ \\
& & & \\
\hline
\end{tabular}

\section{Viral and bacterial dynamic into coastal ponds}

The VLP abundance in the environment was obtained from TEM ultraconcentrate titers by applying the TEM/lysis regression line (Fig. 1B) and the mean TEM recovery rate of VLPs $(77.3 \%$; Table 1$)$.

In June and July 1996, salinity increased continuously during the 2 lunar sampling cycles, from 31.0 to 37.8 practical salinity units (PSU; June 1996) and from 34.6 to 38.9 PSU (July 1996). Temperature decreased during the second half of June and then increased steeply during July. Irradiance was relatively high and constant in June but declined during the last week. In July, the irradiance increased again, with a peak at mid-month (Fig. 2).

Tailed as well as untailed VLPs were each categorised into 6 size-classes based on shape and diameter of the icosahedral capsid (Fig. 3). Two separate categories were the lemon-shaped bacteriophages (LSV; Guixa-Boixareu et al. 1996), and 'Others' (bacilliform and pleomorphic particles, Table 2).

In the pond, total VLP abundance varied between $10^{6}$ and $30 \times 10^{6}$ particles $\mathrm{ml}^{-1}$ over the 2 mo sampling period. During June, total VLP abundance increased rapidly and then levelled off. By contrast, during July, the values were high from the beginning and then declined (Fig. 4). The viral community was dominated by small viruses (size-classes 20 to $44 \mathrm{~nm}$ and 45 to $64 \mathrm{~nm}$; Fig. 4). The viruses $<65 \mathrm{~nm}$ always made up between 70 and $90 \%$ of the total viruses in June and between 62 and $83 \%$ in July (Table 2). The dynamics of these 2 vi- ral classes thus reflected the dynamics of the whole viral population. In mid-July, the third-largest size class (65 to $84 \mathrm{~nm}$ ) was also important: it made up $22 \%$ of all the VLPs, against $28 \%$ for the 20 to $44 \mathrm{~nm}$ and $34 \%$ for the 45 to $64 \mathrm{~nm}$ class.

The proportion of bacteriophages (i.e. tailed and lemon-shaped bacteriophages) increased progressively during each cycle from $4-5 \%$ to $19-23 \%$, in particular towards the end (Fig. 7). At the beginning of each lunar cycle, the tailed phages were almost exclusively small particles (45 to $64 \mathrm{~nm}$ ). Later, the tailed-phage size spectrum diversified: at mid-cycle (20 June and 18 July, respectively), large phages were rather abundant (phages $\geq 105 \mathrm{~nm}$ making up $30 \%$ in June and $36.4 \%$ in July, respectively, of total phages). At the end of the first cycle, 4 size classes (from 45 to $124 \mathrm{~nm}$ ) were well represented. At the end of the second cycle, 3 size classes prevailed (from 45 to $104 \mathrm{~nm})$, but the smallest size class remained dominant (Fig. 5, Table 2). LSV were observed when the salinity exceeded 34 PSU; they represented 5 to $30 \%$ of the total phages.

Bacteria increased steadily during each cycle, from 6

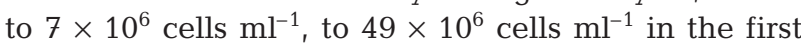
cycle, and to $22 \times 10^{6}$ cells ml $^{-1}$ in July. During June, growth was sustained to the end of the cycle through a 4 -fold explosion of cocci ( $78 \%$ of total bacteria at the last sampling day); during July, growth levelled off toward the second half, with cocci then only represent-

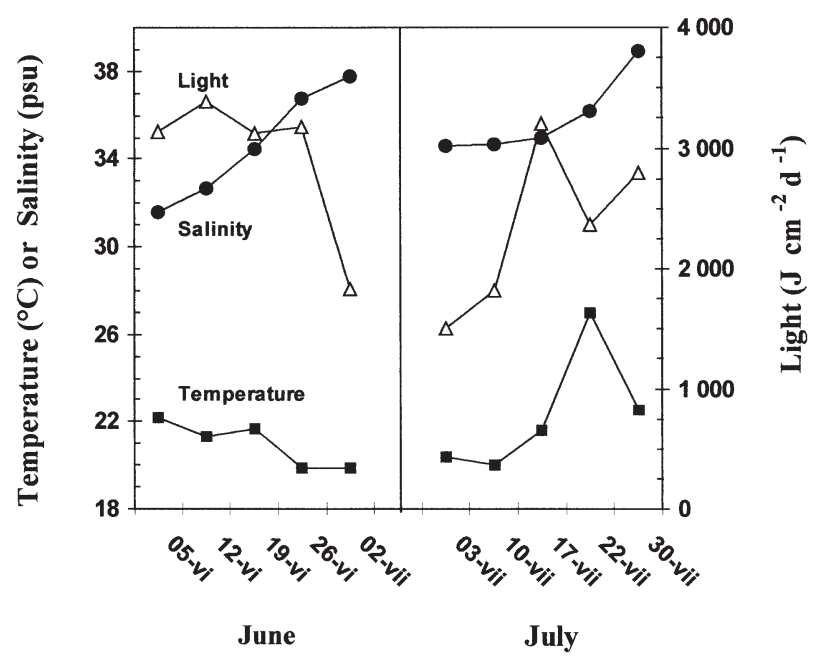

Fig. 2. Environmental parameters for the experimental pond site during 2 lunar renewal cycles of summer 1996. Temperature and salinity at mid-depth $(0.4 \mathrm{~m})$ and irradiance in air measured with an Aanderaa 2770 pyranometer 

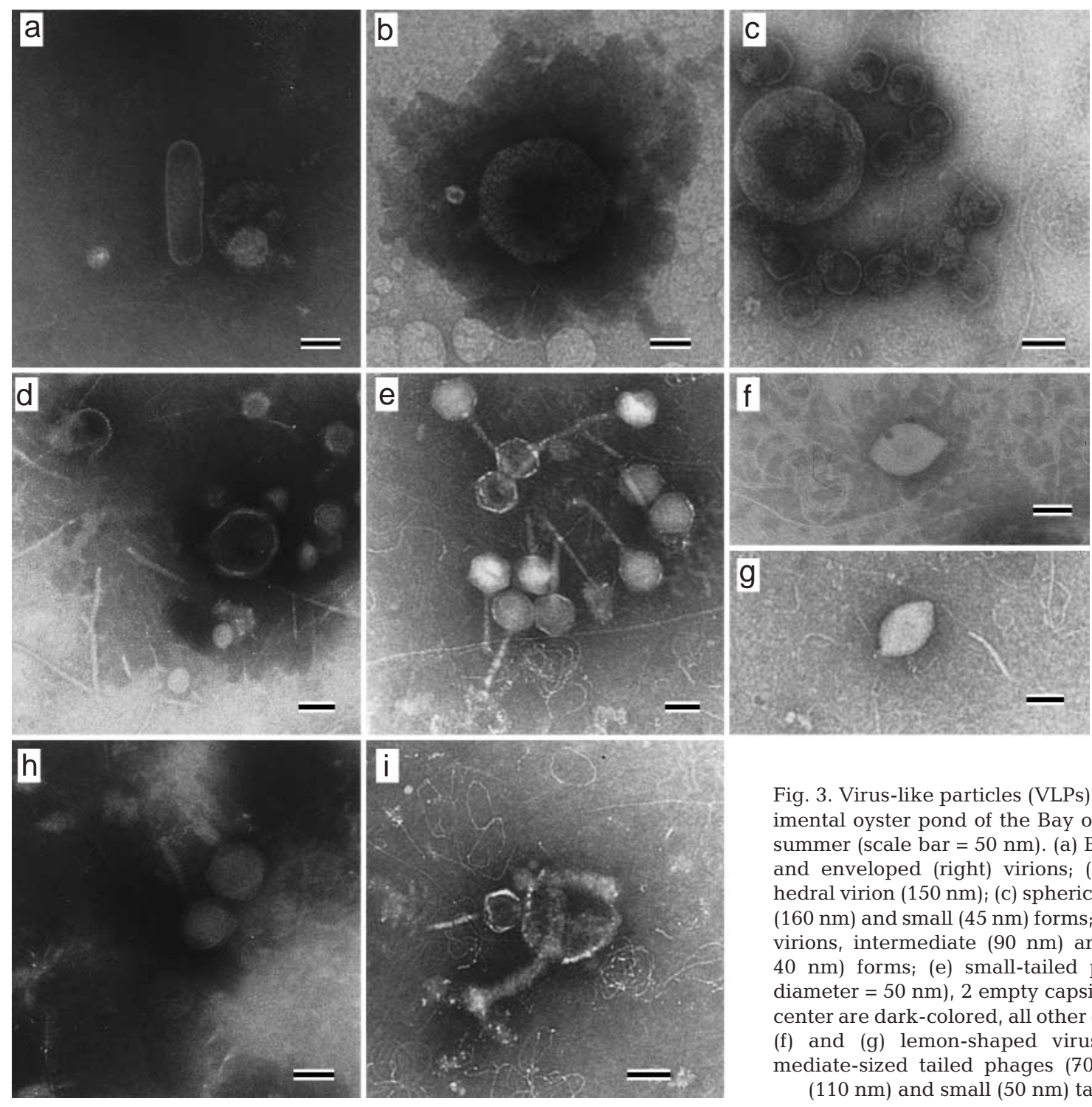

Fig. 3. Virus-like particles (VLPs) from an experimental oyster pond of the Bay of Biscay during summer (scale bar $=50 \mathrm{~nm}$ ). (a) Bacilliform (left) and enveloped (right) virions; (b) large icosahedral virion $(150 \mathrm{~nm}) ;(\mathrm{c})$ spherical virions, large (160 nm) and small (45 nm) forms; (d) icosahedral virions, intermediate $(90 \mathrm{~nm})$ and small (30 to $40 \mathrm{~nm}$ ) forms; (e) small-tailed phages (capsid diameter $=50 \mathrm{~nm}), 2$ empty capsids at upper left center are dark-colored, all other capsids are full; (f) and (g) lemon-shaped virus; (h) 2 intermediate-sized tailed phages $(70 \mathrm{~nm})$; (i) large $(110 \mathrm{~nm})$ and small $(50 \mathrm{~nm})$ tailed phages

Table 2. Size-class distribution of VLP in experimental oyster pond samples taken in 1996. Shown are proportions of total virus (left) and of bacteriophages (tailed plus lemon-shaped virus [LSV]; right). 'Others' are non-icosahedral particles: LSV, bacilliform and pleomorphic virus

\begin{tabular}{|c|c|c|c|c|c|c|c|c|c|c|c|c|c|c|}
\hline \multirow[t]{2}{*}{ Date } & \multicolumn{7}{|c|}{ Total virus ( $\%$ by size class in $\mathrm{nm})$} & \multicolumn{7}{|c|}{ Bacteriophages (\% by size class in $\mathrm{nm}$ ) } \\
\hline & $20-44$ & $45-64$ & $65-84$ & $85-104$ & $105-124$ & $>124$ & Others & $20-44$ & $45-64$ & $65-84$ & 85-104 & $105-124$ & $>124$ & LSV \\
\hline \multicolumn{15}{|c|}{ June lunar cycle } \\
\hline 6 Jun & 65.0 & 25.0 & 0 & 5.0 & 5.0 & 0 & 0 & 0 & 100 & 0 & 0 & 0 & 0 & 0 \\
\hline 20 Jun & 43.5 & 26.5 & 10.0 & 12.5 & 5.5 & 0.5 & 1.5 & 0 & 30.0 & 10.0 & 0 & 20.0 & 10.0 & 30.0 \\
\hline $3 \mathrm{Jul}$ & 31.8 & 40.8 & 11.9 & 6.6 & 5.2 & 1.0 & 2.8 & 0 & 34.2 & 24.4 & 17.1 & 14.6 & 4.9 & 4.9 \\
\hline \multicolumn{15}{|c|}{ July lunar cycle } \\
\hline $4 \mathrm{Jul}$ & 54.7 & 29.1 & 8.7 & 2.8 & 1.7 & 0.3 & 2.8 & 0 & 90.9 & 0 & 0 & 0 & 0 & 9.1 \\
\hline $18 \mathrm{Jul}$ & 28.5 & 34.3 & 22.6 & 3.6 & 6.6 & 2.9 & 1.5 & 0 & 18.2 & 27.3 & 9.1 & 9.1 & 27.3 & 9.1 \\
\hline $31 \mathrm{Jul}$ & 32.9 & 46.0 & 9.4 & 2.8 & 1.8 & 2.8 & 4.2 & 0 & 68.8 & 10.4 & 10.4 & 2.1 & 0 & 8.3 \\
\hline
\end{tabular}




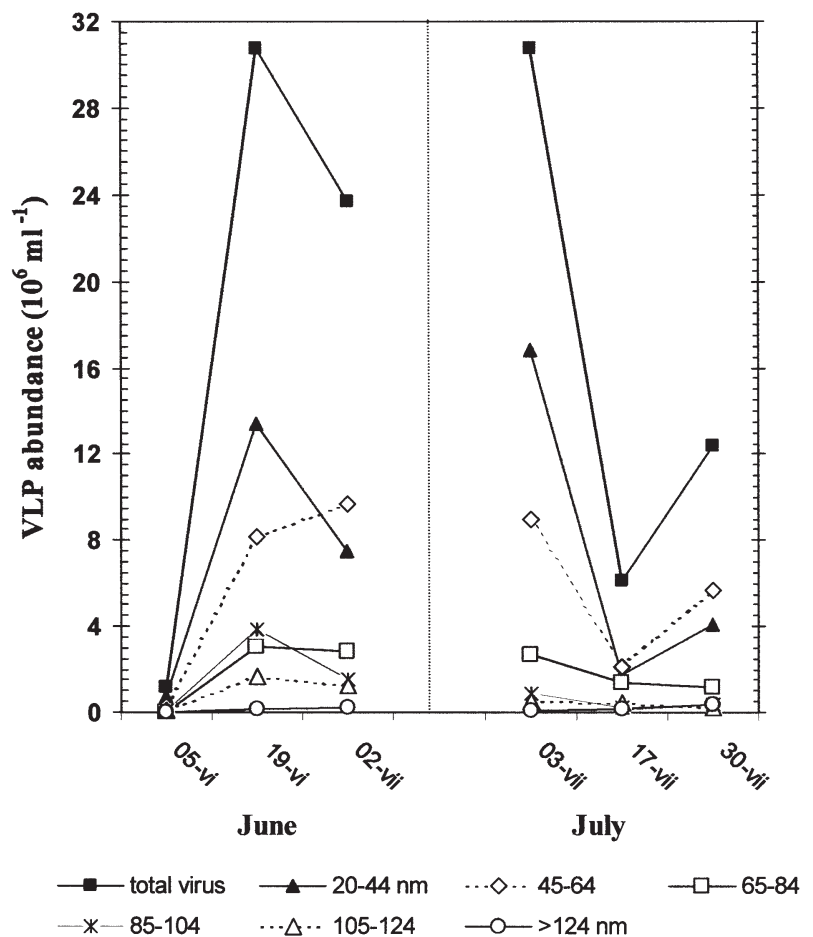

Fig. 4. Dynamics of virus-like particles (VLP) in an experimental oyster pond during 2 lunar renewal cycles in summer 1996. Total virus abundance and 6 size classes as identified by TEM image analysis are shown. Each data point represents a mean from 2 or 3 grids (variability of replicate grid counts: mean $C V=29.4 \%$ )

ing $59 \%$ (Fig. 6). The virus/bacteria ratio varied between 0.19 and 4.36 (ratio of a:b, Fig. 7).

\section{DISCUSSION}

\section{Methods}

TEM was used to quantify and identify the viruses in the pond water. Many investigators have used TEM to estimate viral abundances in aquatic environments (Wommack \& Colwell 2000). Moreover, since TEM is currently the only method available for sizing viruses and determining their ultrastructure, we first needed to improve and validate this method. Viruses were thus identified on the basis of the size of particles, capsomer morphology and on staining characteristics. Furthermore, we visualised potential viral infectivity by distinguishing between full and empty particles (i.e. replete or devoid of nucleic acid) and, in the case of the T2 calibration curve, between the presence or absence of a tail (to identify defective particles). The plaque assay method is a classical virological method to evaluate suspension titers of cultured viruses. However, in field samples, plaque counts cannot evaluate all active

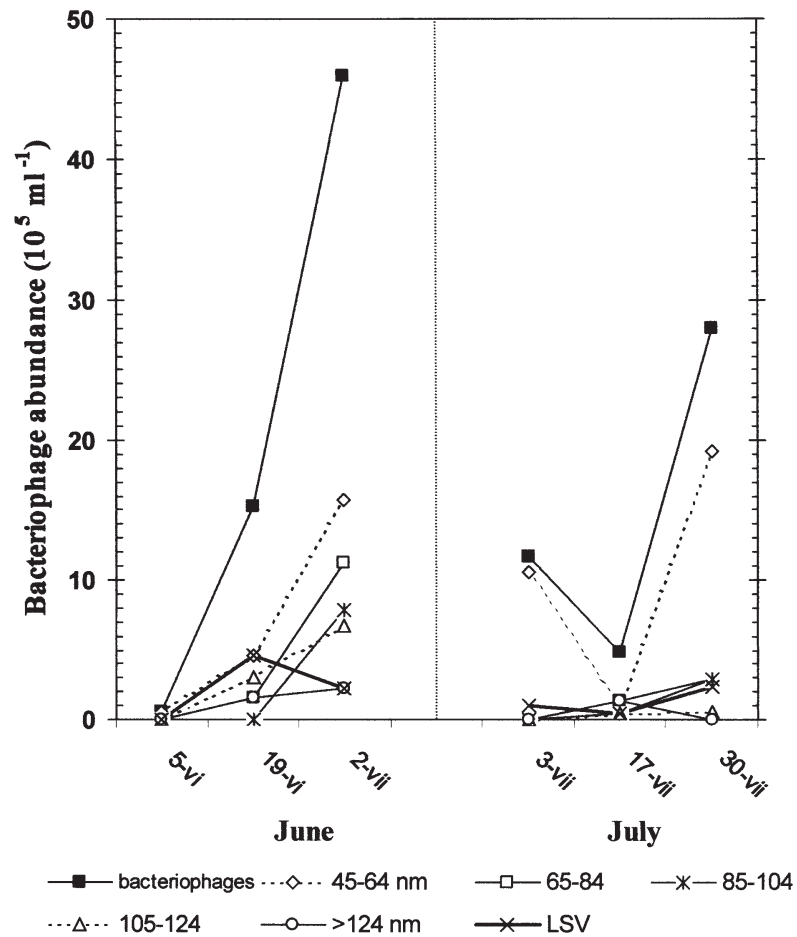

Fig. 5. Dynamics of bacteriophages in an experimental oyster pond during 2 lunar renewal cycles in summer 1996. Total bacteriophage abundance, 5 size classes of tailed phages and lemon-shaped viruses (LSV) as identified by TEM image analysis are shown. Untailed bacteriophages are excluded. Each data point represents a mean from 2 or 3 grids (variability of replicate grid counts: mean CV $=29.4 \%$ )

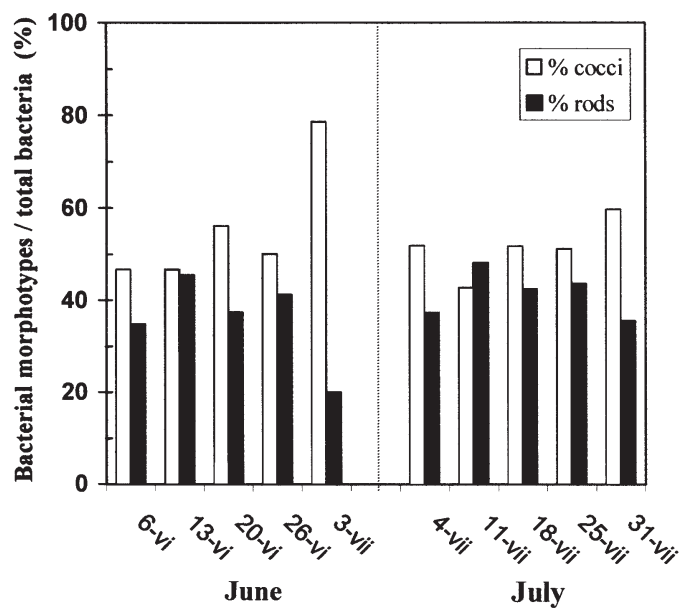

Fig. 6. Percentage of bacterial morphotypes (cocci and rods) during 2 successive lunar renewal cycles in an experimental oyster pond in summer 1996. Not shown are dividing cells (FDC)

viruses because of the specificity of the host cells used. Therefore, we also compared the TEM counts with an epifluorescence method. 


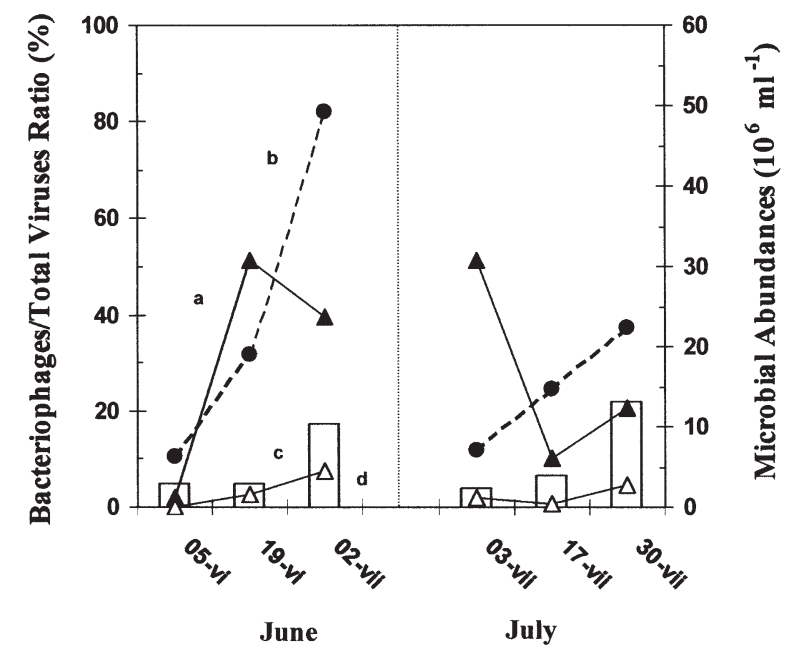

Fig. 7. Comparison of the development of total virus (a), bacteria (b), bacteriophages (c) and the ratio of bacteriophages/total viruses (d) during 2 successive lunar cycles in an experimental oyster pond in summer 1996

Our improved TEM method allows to reduce the interference of high concentrations of suspended matter (mineral particles, cells, detritus, DOM) and salts with the VLP's visualisation on the microscopic grids. Three steps were used: (1) a clarification before the ultracentrifugation; (2) resuspension of the ultracentrifuged pellet in an artificial medium; (3) TEM grids were prepared with a sub-sample of the resuspended pellet. Thus, the grids did not need to be rinsed in order to remove salts. Hennes \& Suttle (1995) reported a 2.2 to 7.2 -fold loss of viruses during their rinsing step in marine samples. Furthermore, the distribution of the particles was rather uniform, while the PTA stain was not always uniformly distributed across the grid surface. Hara et al. (1991) also used a small drop of virus suspension placed on a grid and negatively stained with uranylacetate solution; they counted only the central part of the grid, where the particle distribution was homogenous.

Our results show that on average up to $80 \%$ of VLPs could be recovered when testing the method with T2phages inoculated in LB medium or in distilled water. This indicates that at least $20 \%$ of the T2-phages disappeared during the treatment process. Since we did not see a sufficient number of separated T2-phage tails, we could not use tail counts to account for these losses. Tails may have been degraded due to treatment, may not have been centrifuged entirely, or may not have been deposited on the grids in the same way as heads or defective particles. Furthermore, serial dilutions of our T2-virus increased the percentage of potentially inactive phages (from 11 to $30 \%$ based on electron microscopic observation). This range is com- parable to proportions of inactive virus found by Proctor \& Fuhrman (1992). They report a range of 13 to $48 \%$ of potentially inactive viruses in environmental samples and 1 to $11 \%$ of T-phages in lysates. Our recovery rate is high, since other studies have reported recovery rates of only 13 to $60 \%$ (Suttle \& Chan 1994).

The mean loss of particles due to clarification was not important, and we did not find differences in the overall recovery rates due to the clarification treatment. Nevertheless, the clarification loss estimated through TEM assay was higher than through plaque assay ( 2.55 and $0.21 \%$, respectively). This is because the TEM counts include defective, non-infective, as well as infective particles, while the plaque assays only reveal infective particles.

The low recovery rate of T2-phages (on average $<35 \%$ ) indicates that these phages did not survive well in seawater. The TEM observations confirmed this hypothesis, since we observed a much higher proportion of defective particles as well as disrupted particles (Table 2) as compared to T2-phages inoculated in LB medium. Conversely, the clarification losses of T2phages are comparable in seawater and LB medium ( 0.21 vs $0.17 \%$ and $2.55 \%$ vs $2.34 \%$ for plaque and MET counts, respectively). We did not have a marine virus available for testing the method. Most likely, a marine virus inoculated in its natural medium (seawater) would behave similar to the T2-phage inoculated in a medium (LB) in which it obviously survives well. We conclude that our tests with T2-phage were valid to verify our method.

Thus, our observations showed that the clarification step was useful for counting viruses in seston-rich seawater: viruses were easily counted because they were not obscured on the grid by particulate matter and other dark-stained particles, a general problem indicated in reviews by Fuhrman (1999) or Wommack \& Colwell (2000).

Concerning the intercalibration methods, a slope of unity between DAPI and lysis counts (Fig. 1A) indicates that the relative difference between the 2 methods (cf. the observed mean DAPI/lysis ratio of 0.158) was constant and independent of the virus concentration. By contrast, the slopes of the TEM/lysis and TEM/Dapi calibrations differed from unity (Fig. 1B,C), showing an increasing ratio at titers below $10^{9}$ TEMcounted particles $\mathrm{ml}^{-1}$ in the concentrated fraction (corresponding to an environmental concentration of about 1 to $2 \times 10^{6} \mathrm{VLP} \mathrm{ml}^{-1}$ ). We attribute this error to the increasing tendency of the particles to aggregate when lower concentrations are applied on the TEM grid. Moreover, the error is magnified by the fact that the conversion factor for TEM is greater than for optical microscopy (DAPI). At $<10^{8}$ particles $\mathrm{ml}^{-1}$, the distribution was too contagious to yield representative 
electron microscopic observations. This could have been compensated by increasing the number of fields observed, or scanning the entire grid, which would have required unreasonably long sample processing times.

Some workers reported opposite TEM/DAPI trends: at viral abundances exceeding $10^{6} \mathrm{ml}^{-1}$, TEM were $80 \%$ of DAPI counts (Hara et al. 1991, Weinbauer \& Suttle 1997), while $<10^{6} \mathrm{VLP} \mathrm{ml}^{-1}$, the TEM and DAPI counts were comparable (Weinbauer \& Suttle 1997). By contrast, TEM exceeded DAPI counts of VLP in a seawater microcosm experiments (TEM/DAPI 7 - 63; Guixa-Boixereu et al. 1999). Assessments of T2 virus added to artificial seawater produced variable results: Paul et al. (1991) reported TEM/DAPI ratios between 0.5 and 3. Our TEM counts of T2 and of VLP in marine water tended to be higher or equal to DAPI counts, with most TEM/DAPI ratios included in the range reported by Paul et al. (1991).

Recently other fluorochromes have been used to estimate viral abundance: Yo-Pro and SYBR-green 1; YoPro counts were on average 1.5- to 2.3-fold higher than TEM counts (Hennes \& Suttle 1995, Weinbauer \& Suttle 1997) and SYBR-green 1 about 1.3-fold higher (Noble \& Fuhrman 1998). It would indeed have been useful to include additional calibration by one of these fluorochromes, in particular with the modified EMYO-Pro protocol (Xenopoulos \& Bird 1997) as recommended by Betharel et al. (2000). However, since the calibrations showed valid linear relations, we considered that additional fluorochrome calibrations would not yield more information than obtained by the TEM method (abundance together with size and identification of the VLPs).

\section{Field observations}

We examined the influence of tailed phages on the dynamics of bacteria in an oyster pond ecosystem. The VLP's abundance (1 to $\left.30 \times 10^{6} \mathrm{ml}^{-1}\right)$ was in the range of data of estuarine surface water $\left(2.6 \times 10^{6}\right.$ to $3 \times$ $10^{8} \mathrm{ml}^{-1}$; Wommack \& Colwell 2000). Tailed VLPs were less abundant than non-tailed VLPs, which has been generally observed in marine waters (Børsheim et al. 1990, Hara et al. 1991). Most investigators believe that the majority of VLPs in marine samples are bacteriophages. For instance, Børsheim et al. (1990) justified this hypothesis because they found a high VLP proliferation rate in an incubation experiment where only $50 \%$ of the viruses in the upper size classes $(\geq 60 \mathrm{~nm})$ and none in the $<60 \mathrm{~nm}$ size-class had tails.

Our results contradict this hypothesis, because total VLP abundance in the pond did not appear to be directly linked to bacterial abundance; however the bacteriophage abundance was positively related to the evolution of bacterial numbers and to the ratio of bacteriophages/total viruses (Fig. 7). The latter observation would indicate that untailed bacteriophages (excepting Fuselloviruses) did not play a major role in bacterial lysis. This is not surprising, because $96 \%$ of all known bacteriophages are tailed (Wommack \& Colwell 2000). Moreover, very small virus (20 to $44 \mathrm{~nm}$ ) represented the dominant fraction at the beginning of each sampling period (68\% in June, $54 \%$ in July) and then always remained at about $28 \%$. These very small viruses were non-tailed. In general, marine bacteriophages in this size-class are rare (Børsheim 1993). Other very small non-tailed bacteriophages (e.g. Microviridae, Leviviridae) tend to be specific to enterobacteria (Murphy et al. 1995).

Thus our results suggest that the best way to characterise bacterial lysis by the viral community would be to study the dynamics of tailed VLP and virus sizeclasses together with total viral abundance. Investigators using only total VLP counts likely overestimated the role of virus on bacterial dynamics. In fact, we suggest that viruses specific to non-bacterial hosts (such as the above mentioned very small VLPs (20 to $44 \mathrm{~nm}$ ) will need to be better identified and studied, in order to confirm their specificity to eukaryotes.

The limitation of bacterial growth during the second sampling cycle was linked to a regular increase of the ratio of bacteriophages/total viruses as well as a dominance of 45 to $64 \mathrm{~nm}$ tailed phages (about $68 \%$ ), while the ratio between bacterial cocci and rods changed little. By contrast, in late June the bacterial population growth corresponded to a greater diversity of tailed phages (4 size classes, as opposed to only 3 in July) and dominance of the larger-tailed phages $(66 \% \geq 65 \mathrm{~nm})$. Moreover, cocci forms became dominant over rods, which stayed constant. Thus, the growth of cocci in June appeared to be linked to the greater abundance of the large-tailed phages. This association may be related to a preferential development of large-tailed phages within cocci: Weinbauer \& Peduzzi (1994) reported a positive relation between cocci and large, tailed intracellular phages $(65 \%$ of viruses in cocci were $>60 \mathrm{~nm}$ ).

The LSV viruses appear to belong to the family of Fuselloviridae, in agreement with the description of their multiplication cycle by Murphy et al. (1995). These are viruses of Archaebacteria and UV irradiance stimulates their replication and the release of particles without cell lysis (Zillig et al. 1988). We also have found square Archaebacteria in this coastal pond. They occurred during the year following this study. A link between the LSV found in 1996 and the Archaebacteria found in 1997 cannot be excluded but requires further investigation. 
In summary, we have developed a new method to concentrate viruses and quantify VLPs by TEM in coastal marine marsh water characterised by high concentrations of particulate matter. This method enabled us to describe the virus-bacteria dynamics in a coastal marine wetland pond. The first results indicate that tailed phages appear to be the principal bacterial predators in this environment. They are to be completed by detailed investigations of the virus-host interactions and other factors influencing bacterial dynamics in coastal marshes, such as the predatory action of protozoa and the study of the burst-size of bacteria.

Acknowledgements. This work has been partly funded by the French Programme National en Océanographie Côtière (PNOC, chantier atlantique 1996-2000) as preliminary work for the cruises BIOMET. We thank Olivier Robin for field sampling, Dr. Gérard Blanchard, as well as 3 anonymous referees for a critical and constructive review of the manuscript.

\section{LITERATURE CITED}

Ackermann H-W (2001) Le matin des bactériophages. Virologie 5:35-43

Adams MH (1959) Bacteriophages. Wiley-Interscience, New York

Azam F, Fenchel T, Gray JG, Meyer-Reil LA, Thingstad T (1983) The ecological role of water-column microbes in the sea. Mar Ecol Prog Ser 10:257-263

Bergh O, Børsheim KY, Bratbak G, Heldal M (1989) High abundance of viruses found in aquatic environments. Nature 340:467-468

Betharel Y, Sime-Ngando T, Amblard C, Laveran H (2000) A comparison of methods for counting viruses in aquatic systems. Appl Environ Microbiol 66:2283-2289

Boehme J, Frischer ME, Jiang SC, Kellogg CA, Pichard S, Rose JB, Steinway C, Paul JH (1993) Viruses, bacterioplankton, and phytoplankton in the southeastern Gulf of Mexico: distribution and contribution to oceanic DNA pools. Mar Ecol Prog Ser 97:1-10

Børsheim KY (1993) Native marine bacteriophages. FEMS Microbiol Ecol 102:141-159

Børsheim KY, Bratbak G, Heldal M (1990) Enumeration and biomass estimation of planktonic bacteria and viruses by transmission electron microscopy. Appl Environ Microbiol 56:352-356

Bratbak G, Heldal M, Norland S, Thingstad TF (1990) Viruses as partners in spring bloom microbial trophodynamics. Appl Environ Microbiol 56:1400-1405

Cochlan WP, Wilkner J, Steward GF, Smith DC, Azam F (1993) Spatial distribution of viruses, bacteria and chlorophyll a in neretic, oceanic and estuarine environments. Mar Ecol Prog Ser 92:77-87

Crottereau C, Delmas D (1998) Exoproteolytic activity in an Atlantic pond (France): estimates of in situ activity. Aquat Microb Ecol 15:217-224

Danovaro R, Serrest M (2000) Viral density and virus-tobacteria ratio in deep-sea sediments of the eastern Mediterranean. Appl Environ Microbiol 66:1857-1861

Delmas D, Frikha MG, Reymond H, Linley EAS, Collos Y (1992) Long term microbial community dynamics in a coastal marine pond. Mar Microb Food Webs 6:39-54

Dupuy C, Pastoureaud A, Ryckaert M, Sauriau PG, Montanié $\mathrm{H}$ (2000) Impact of the oyster Crassostrea gigas on a microbial community in Atlantic coastal ponds near La Rochelle. Aquat Microb Ecol 22:227-242

Frikha MG, Linley EAS, Delmas D (1987) Evolution annuelle et saisonnière de la microbiomasse d'une claire à huîtres: importance des populations bacterioplanctoniques. Oceanis 13:433-447

Fuhrman JD (1999) Marine viruses and their biogeochemical and ecological effects. Nature 399:541-548.

Guixa-Boixareu N, Calderón-Paz JI, Heldal M, Bratbak G, Pedrós-Alió C (1996) Viral lysis and bacterivory as prokaryotic loss factors along a salinity gradient. Aquat Microb Ecol 11:215-227

Guixa-Boixereu N, Lysnes K, Pedrós-Alió C (1999) Viral lysis and bacterivory during a phytoplankton bloom in a coastal water microcosm. Appl Environ Microbiol 65:1949-1958

Hara S, Terauchi K, Koike I (1991) Abundance of viruses in marine waters: assessment by epifluorescence and transmission electron microscopy. Appl Environ Microbiol 57: 2731-2734

Hara S, Koike I, Terauchi K, Kamiya H, Tanoue E (1996) Abundance of viruses in deep oceanic waters. Mar Ecol Prog Ser 145:269-277

Hennes KP, Suttle CA, (1995) Direct counts of viruses in natural waters and laboratory cultures by epifluorescence microscopy. Limnol Oceanogr 40:1050-1055

Jumars PA, Perry DL, Baross JA, Perry MJ, Frost BW (1989) Closing the microbial loop: dissolved carbon pathway to heterotrophic bacteria from incomplete ingestion, digestion and absorption in animals. Deep-Sea Res 36:483-495

Maranger R, Bird DF (1995) Viral abundance in aquatic systems: a comparison between marine and fresh waters. Mar Ecol Prog Ser 121:217-226

Maranger R, Bird DF, Juniper SK (1994) Viral and bacterial dynamics in arctic sea ice during the spring algal bloom near Resolute, N.W.T., Canada. Mar Ecol Prog Ser 111: 121-127

Mathias CB, Kirschner KT, Velimirov B (1995) Seasonal variations of virus abundance and viral control of the bacterial production in a backwater system of the Danube river. Appl Environ Microbiol 61:3734-3740

Murphy FA, Fauquet CM, Bishop DHL, Ghabrial SA, Jarvis AW, Martelli GP, Mayo MA, Summers MD (1995) Virus taxonomy. 6th Rep Int Comm Taxonomy of Viruses. Springer-Verlag, Vienna

Noble RT, Fuhrman JA (1998) Use of SYBR green I for rapid epifluorescence counts of marine viruses and bacteria. Aquat Microb Ecol 14:113-118

Paul JH, Jiang SC, Rose JB (1991) Concentration of viruses and dissolved DNA from aquatic environments by vortex flow filtration. Appl Environ Microbiol 57:2197-2204

Pomeroy LR (1974) The ocean's food web, a changing paradigm. BioScience 24:499-504

Porter KG, Feig YS (1980) The use of DAPI for identifying and counting aquatic microflora. Limnol Oceanogr 25:943-948

Proctor LM, Fuhrman JA (1990) Viral mortality of marine bacteria and cyanobacteria. Nature 343 (6253):60-62

Proctor LM, Fuhrman JA (1992) Mortality of marine bacteria in response to enrichments of the virus size fraction from seawater. Mar Ecol Prog Ser 87:283-293

Robert JM, Maestrini SY, Héral M, Rincé E, Dreno JP, Beker L (1982) Enrichissement expérimental d'eaux printanières de claires à huîtres en Baie de Bourgneuf (Vendée, France): augmentation de la biomasse et utilisation des éléments nutritifs par les algues unicellulaires. Hydro- 
biologia 96:53-63

Suttle CA (1993) Enumeration and isolation of viruses. In: Kemp PF, Sherr BF, Sherr EB, Cole JJ (eds) Handbook of methods in aquatic microbial ecology. Lewis Publishers, Boca Raton, FL, p 121-134

Suttle CA, Chan AM (1994) Dynamics and distribution of cyanophages and their effect on marine Synechococcus spp. Appl Environ Microbiol 60:3167-3174

Suttle CA, Chan AM, Cottrell MT (1990) Infection of phytoplankton by viruses and reduction of primary productivity. Nature 347:467-469

Weinbauer MG, Peduzzi P (1994) Frequency, size and distribution of bacteriophages in different marine bacterial morphotypes. Mar Ecol Prog Ser 108:11-20

Weinbauer MG, Suttle CA (1997) Comparison of epifluorescence and transmission electron microscopy for counting

Editorial responsibility: Fereidoun Rassoulzadegan, Villefranche-sur-Mer, France viruses in natural marine waters. Aquat Microb Ecol 13: 225-232

Wilhem SW, Suttle CA (1999) Viruses and nutrient cycles in the sea. Bioscience 49:781-788

Wommack KE, Colwell RT (2000) Virioplankton: viruses in aquatic ecosystems. Microbiol Mol Biol Rev 64:69-114

Xenopoulos MA, Bird DF (1997) Virus à la sauce Yo-Pro: microwave-enhanced staining for counting viruses by epifluorescence microscopy. Limnol Oceanogr 42: 1648-1650

Zar JH (1996) Biostatistical analysis. Prentice Hall, Englewood Cliffs, NJ

Zillig W, Reiter W-D, Palm P, Gropp F, Neumann H, Reitenberger M (1988) Viruses of Archaebacteria. In: Calender R (ed) The bacteriophages. Plenum Press, New York, p 517-558

Submitted: February 21, 2001; Accepted: April 4, 2002

Proofs received from author(s): June 18, 2002 